\title{
Can Sound Corporate Governance Alleviate Corporate Failure? A Study of the Zimbabwean Financial
} Services Sector

\author{
Banele Dlamini*, Julius Tapera, Shynet Chivasa \\ Lupane State University, Zimbabwe \\ dlabukhosi@gmail.com*, juliustapera@gmail.com, shynet.chivasa5@gmail.com
}

\begin{abstract}
This study, using the Ordinary Least Squares (OLS) Regression Model, investigated the extent to which good corporate governance practices can minimise or alleviate corporate failure in the Zimbabwean Financial Services Sector. The results of the study reflected that sound corporate governance has a positive effect on corporate success and can alleviate corporate failure. It is thus recommended that financial institutions continuously adhere to sound corporate governance practices to guarantee corporate success and alleviate the collapse of financial institutions as has been witnessed in the past. The findings of the study will assist policy makers, regulators and players in the financial services sector to adhere to sound corporate governance practices, given its impact on corporate success. Further research could be carried out with regards the implementation of sound corporate governance in parastatals, quasi-government institutions and private sector companies in other sectors other that the financial services sector and how it can be monitored or enforced.
\end{abstract}

Keywords: Corporate governance, financial services sector, capital structure, company size, corporate success

\section{Introduction}

The Zimbabwean financial services sector was characterized by significant growth at the turn of the $21^{\text {st }}$ century when the Zimbabwean government "liberalized" the sector, relatively relaxing the requirements to allow indigenous player to enter the industry. Hardly a decade into this boom of the financial services sector did we start witnessing a series of closure of institutions within the financial services industry, forced mergers, unbundling of merged institutions and numerous other reforms within the sector. In 2009 the country introduced the multi-currency system to resuscitate the economy which had suffocated and collapsed during the Zimbabwean dollar meltdown era. Even during the multi- currency regime, since 2012 to 2015 the financial services sector continued to suffer a decline with banks such as AfrAsia Bank Zimbabwe Limited, Renaissance Merchant Bank, Interfin Bank, Genesis Investment Bank, Capitol Bank and Royal Bank closing due to poor corporate governance inter alia (Munzwembiri, 2015), Bank failure is not solely a shift in the architecture of the financial service sector but represents lost savings, lost pension funds, causing company closures and job losses. The huge cost is the loss of confidence in the entire financial services system and it also negatively affect potential investment opportunities in the economy.

This paper investigates the extent to which good corporate governance practices can avert or alleviate corporate failure in the Zimbabwean Financial Services Sector.Unlike previous studies (Kumar \& Sudesh, 2016; Chidoko and Mashavira, 2014) which focused on comparative analysis of domestic and multinational banks corporate governance practices, this study focuses on the link between corporate performance and sound corporate governance.The study will therefore inform policy and assist the Zimbabwean Financial Services Sector in the reduction of corporate failure in the industry since corporate governance is a critical aspect for the survival and growth of entities and it is also a pivotal factor in turning around Zimbabwe's economy(Mahmud, Ahmed, and Mahajan, 2008). Sustainability and success of the industry will be achieved when corporate governance practitioners uphold sound corporate governance principles and practices. The organization of this paper is as follows; it will give the objectives of the study and briefly explain the meaning and principle of corporate governance, reveal the relationship between sound corporate governance and company failure, and determine how bad corporate governance can lead to corporate failure. Conclusion will be made based on the findings of the study and recommendation to improve corporate governance in the Financial Services Sector in Zimbabwe.

\section{Research Objectives}

- To evaluate the impact of sound corporate governance practices on corporate performance in the Zimbabwean financial services sector, 
- To identify other causes of corporate failure in the Zimbabwe's financial services sector

\section{Literature Review}

Corporate governance: Definition: Corporate governance definitions varies from a narrow scope of ownership structures to a wider scope which defines the other dimensions of corporate governance such as Board of Directors size and composition, risk management practices, executive compensation and rules and regulations of organizations (Changezi and Saeed, 2013). Corporate governance is a system by which companies are directed and controlled (Cadbury Committee, 1992). According to Khan (2011), corporate governance is the broad term that describes the processes, customs, policies, laws and institutions that directs the corporations in the way they administer and control their operations. Eroke (2007) stated corporate governance as a system by which creditors and investors get assurance about adequate and reasonable return rates on investment.

Sound corporate governance principles: According to Okeahalam and Akinboade (2003) sound corporate governance promotes efficiency, effectiveness and sustainable corporations in creation of wealth, employment, welfare of society, solutions to emerging challenges and managed with integrity, probity, transparency and protection of stakeholder rights. The RBZ (2004) report states that good corporate governance and integrity in business are the bedrock and foundation to sustainable economic and social prosperity. Poor corporate governance weakens company's potential and financial strength whilst opening ways for financial difficulties and frauds. Companies which follow the best corporate governance raise capital easier and in the long run are more financially stable and successful than companies that have poor corporate governance (Todorović, 2013). It is in light of the identified possible benefits of sound corporate governance that the study seeks to unearth the technical relationship between sound corporate governance and corporate performance. According to Chidoko and Mashavira (2014) there are several accepted basic elements of sound corporate governance that are applicable to both the private and public sector. These include discipline, fairness, independence, accountability, transparency responsibility and social responsibility.

Basel Committee (2010) identified the principles of sound corporate governance for optimum operation level as;

- It is the responsibility of the board to approve and oversee the implementation of the bank's strategic goals, corporate values and corporate governance. The board should also have an oversight of senior management activities.

- Board members should be qualified and trained for their positions and understand their roles in the affairs of the bank.

- Appropriate governance practices should be defined for the work of the board and means to ensure that such practices are adhered to with prescribed intervals for review and on-going improvements.

- The board of a parent entity in a group structure has the overall responsibility to ensure that adequate corporate governance policies, business and risks of the group across are followed.

- The board through its direction should ensure that senior management activities are consistent with the bank's strategy, risk management and policies approved by the board.

- The board should ensure that the banks have an effective risk management function and internal controls system with adequate authority, access to the board, independence and sufficient resources.

- Identification of risk and risk monitoring should be an on-going firm-wide process keeping pace with any internal and external changes to the bank's risk profile.

- Robust internal communication about bank risk is essential for effective risk management, across the entity and through reporting to the senior management and board.

- Internal audit functions and external auditors work should effectively utilise the work by senior management and the board.

- The senior management and board should understand the risk and bank's operational structure.

- The governance of the bank should be transparent to its depositors, market participants, shareholders, and all relevant stakeholders. 
For the purposes of this study the researchers are going to concentrate on the following principles only; board structure and size, board qualifications, board composition and diversity, and board practices.

Board Structure and Size: According to Vaithilingam et al. (2006) board structure is how the organisation is organised in terms of the board of directors. Board size is the total number of directors that an organisation has in its board structure. This is calculated, as the total minimum number of directors (at least five) needed by the central bank over the total number of directors in the board of directors at the end of the annual financial year (Shungu et al., 2015). Studies by Larcker et al. (2010); Hallock (1997); Nguyen (2009) have shown that board size tends to be correlated with company revenue; large boards have greater costs and decision making is slow while there are more resources, greater specialization.

Board Qualifications: Board members should be and remain qualified through training for their positions and should have the ability to exercise sound judgment on the affairs of the bank (Basel committee, 2010). According to Mettler-Toledo (2015) the Board of Directors should be made up of successful members who demonstrate integrity, honesty, knowledge of the firm affairs, a general understanding of the company's business, and an ability to work well together. Diversification in business background, gender, ethnicity and area of expertise should be considered. The Board should be composed of individuals who are able to; demonstrate management ability at senior levels in successful organizations; be employed in positions of significant responsibility and possess experience related to areas of importance of the company. The relevant skills would enable the board to understand the affairs of the organisation which then improves the decision making process.

Board Composition and Diversity: Board composition is concerned with board independence, diversity and CEO duality. Corporate governance best practice recommends that organisations have high levels of board independence whereby there is a higher number of independent outside directors in comparison to both inside directors and related or affiliated outside directors. Proponents of this notion argue that a board with a higher level of independence is more vigilant in monitoring managerial behaviours and curb self-interest, and more objective in their decision making. Board diversity refers to the mix of men, women, younger members, long-term members, people from different age brackets, and people with different ethnic groups and racial backgrounds on a corporate board (Enobakhare, 2010; Björklund, 2010; Fairfax, 2011). Carter, Simpkins and Simpson (2003) evaluated the relationship that exist between company value and board diversity for Fortune 1000 firms and found a significant positive relationship between women or minorities on the board and firm value.

Another study by the Credit Suisse Research Institute revealed that companies with one or more women directors over a period of six years had higher net income growth than those that had no women on the board. A total of 2,400 companies were examined from across the globe and the result reflected that net income grew by $14 \%$ for companies that had women directors in comparison to $10 \%$, for companies whose boards did not have women directors. Increasing board diversity is very important, but there is a catch on that; the more diverse a board becomes, the more difficult board communications become (Björklund, 2010). Various arguments have been advanced on the concept of CEO duality, some being for and others being against the concept. CEO duality refers to a situation where the CEO of an organization doubles up as the board chairperson. CEO duality has been criticised by some authors as lowering the level of supervision on the management team, which adversely affects company performance (Levy, 1982).

Board Practices: The board has overall responsibility including approving and overseeing the implementation of the overall strategy, corporate governance and company values. It is the responsibility of the board to have an oversight of senior management. The board should exemplify by strictly adhering to proper sound governance practices which it had defined for its own work in the organisation. The board should ensure that practices in place assist the board in carrying out its duties more effectively, are followed and periodically reviewed for on-going improvement and these send important signals both internally and externally about the nature of organisation the bank aims to be (Basel Committee, 2010). According to Larcker (2010) boards are often described in terms of their salient structural features: size, independence, committees, and diversity. 
Corporate Failure: Jayaraman, Nanda and Ryan (2015) assert that, following the series of corporate failure in the early 2000s, there have been an increased number of calls, by governance activists and policy makers, for the separation of the roles of CEO and Board Chairman. These calls have been premised on the notion that there is very limited scope of objective supervision and monitoring of the CEO performance by an independent Board Chairman, which is one of the major agency problems. They however make it clear that while there have be such calls for separation of roles, earlier research and their own research have not been conclusive on causality of CEO duality to corporate failure. On one hand, findings from various researches supported CEO duality (Palmon and Wald, 2002; Faleye, 2007; Dey, Engel and Liu 2009; Yang and Zhao, 2012), while on the other hand other researches supported the separation of the roles of CEO and Board Chairman (Dahya, McConnell and Travlos, 2002; Dahya and McConnell, 2007). Earlier research by Brickley, Coles and Jarrel (1997) had also been inconclusive, with the researchers indicating that the separation of CEO and Board Chairman Roles has both potential benefits and potential costs. From this summary of research findings from different researches, corporate failure cannot be conclusively attributed to CEO duality.

\section{Figure 1: Conceptual Model}

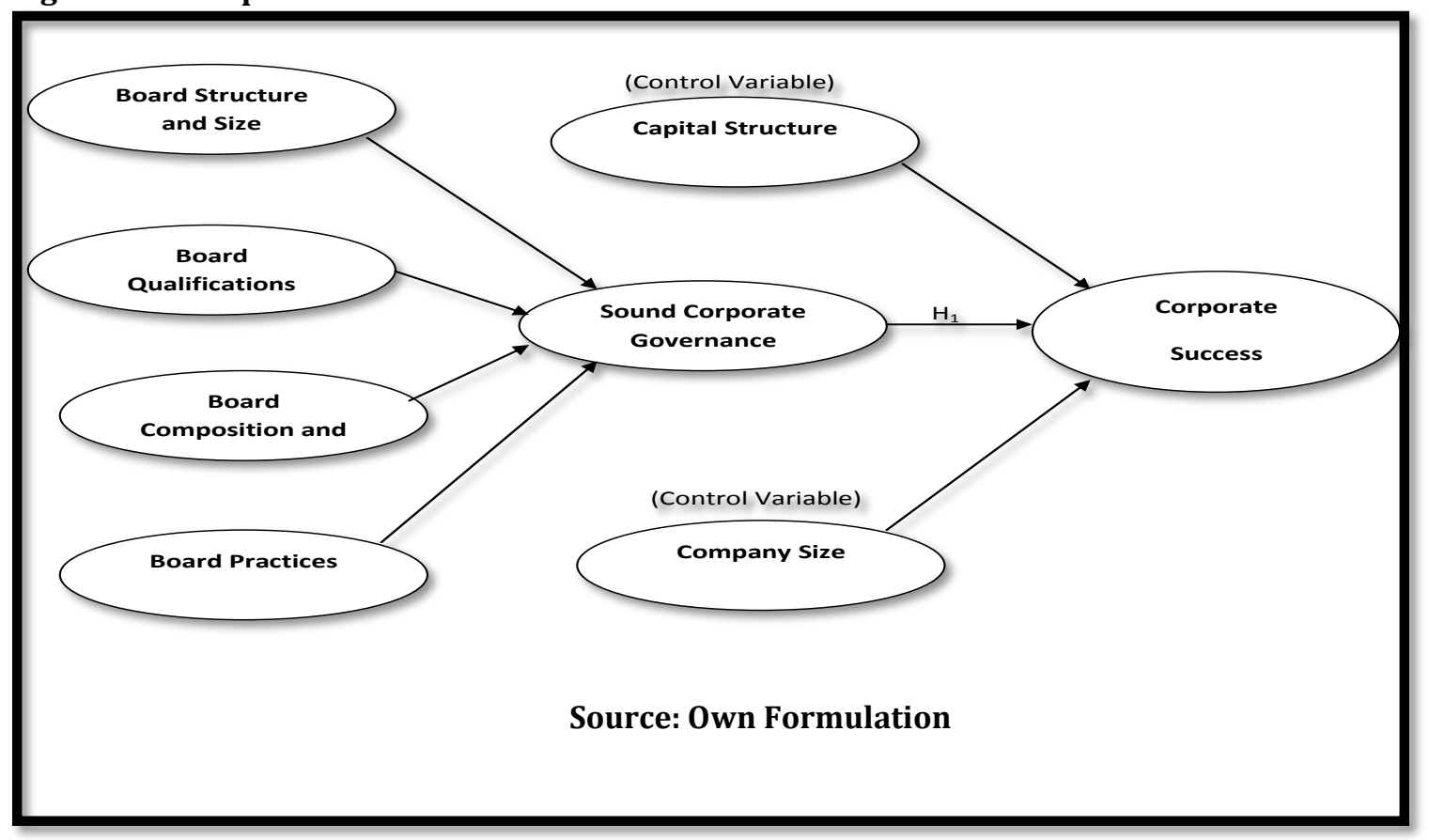

\section{Hypothesis}

$\mathrm{H}_{1}$ - There is a positive relationship between sound corporate governance and corporate success

Empirical Evidence: Bank governance addresses a range of issues, including who will run the bank, what will be the structure of the board of directors, how will the board carry out its duties, what financial incentives and other factors will be used in aligning all stakeholder interest (Benton, 2007). Companies that maintain the highest standards of governance reduce many risks that emanate from routine operations. Because of better performance and returns, such companies are able to attract investors who will help finance further development and growth. Bushee et al. (2007), as well as Leuz et al. (2007) support this claim that investors exhibit preference for well-governed firms. Research done by Todorović, (2013) indicates that there is correlation and impact of implementation of principles of corporate governance on performance of companies, it shows that investors have a tendency to inject more funding in companies which have sound governance systems. Studies by Gompers et al. (2003) and Black et al. (2003) revealed that organisations with sound corporate governance principles enjoy higher profits, higher valuations, and higher sales growth. 


\section{Methodology}

This research depends mainly on secondary data, which was obtained from the annual reports of various institutions in the Zimbabwean Financial Services Sector for a six (6) year period, "2010-2015." This period was selected because it is the time during which the country was recovering from an economic recession that had started around 1999 and it is the multi-currency regime period. The content analysis was used in the evaluation of textual data so as to interpret contextual meaning of text data (Tesch, 1990; Hsieh and Shannon, 2005). It is recommended that when using contextual analysis technique, a set of categories should be established into which data is coded (Stray, 2008); Board practices, Board structure and size, Board Qualifications, Board composition and Diversity were used to establish Sound Corporate Governance (SCG) score on the elements reported by the banks on Corporate Governance. In measuring corporate success, financial accounting ratios, return on assets (ROA) and return on equity (ROE) were used. An Ordinary Least Squares (OLS) Regression Model was used to determine the relationship between corporate success and sound corporate governance and the model was tested.Company size and capital structure were used as control variables in the regression model.

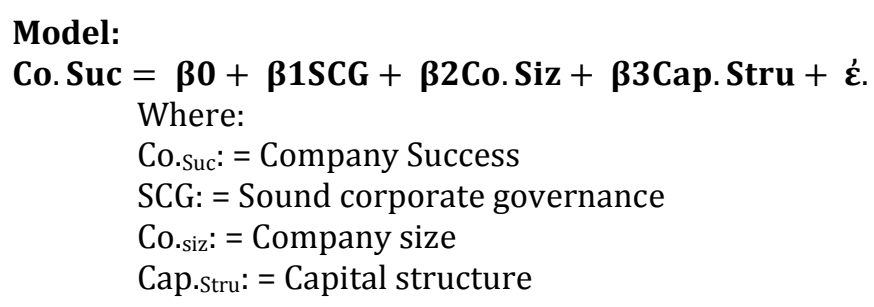

All banks operating in Zimbabwe since 2010 including those that have since closed were considered in this research. The inclusion of all banks assists in assessing the corporate governance practise; comparing practices of both the closed and the currently functional banks. The data was gathered through reviewing various reports by the regulatory authority, the Reserve Bank of Zimbabwe (RBZ), and industry surveys in order to analyse corporate governance developments within the sector.

\section{Results and Discussion}

Results summary: The results revealed an average Tobin's q ratio of 0.6 with the highest of 14.90 and the lowest of 0.05 . This means that on average most financial institutions in Zimbabwe are performing well. Only $25 \%$ of the financial institutions that were reviewed have a Tobin's q ratio which is greater than 1 . Theory argues that the lower Tobin's q ratio can be due to other factors such as diversification of the organization. This is not the case in Zimbabwe as none of the studied financial institutions is diversified. Thus the low Tobin's q is wholly due to poor performance. The poor performance of the financial institutions might be due to poor performance of the stock market. The Zimbabwe Stock Exchange (ZSE)'s general downward performance might be resulting in undervaluing of the financial institutions. Of the institutions studied, $45 \%$ of the companies have a well constituted board structure with qualified members who also have the relevant experience. $30 \%$ had sound board practices, and with other boards having a problem of one centre of power which has an effect on strategic business decision making process. Conflict of interest was rampant as $40 \%$ of the companies had board members who are shareholders of the competitors company which presents a serious case of conflict of interest and this has negatively affected the performance of the financial institutions in Zimbabwe. The stock pledge ratio of 12.3 has a negative effect on firm performance. A high ratio has an effect on the stock exchange as there are problems of insider trading which might negatively impact on the share price, thus the market valuation of the company. The descriptive results are summarized below; 
Table 1: Descriptive results

\begin{tabular}{lllll}
\hline & Mean & Std Dev & Min & Max \\
\hline SCG & 0.562 & 0.268 & 0.02 & 9.051 \\
CO size & 9.34 & 1.11 & 4.33 & 18.23 \\
Tobin's Q & 0.6 & 0.35 & 0.05 & 14.96 \\
Pledge & 12.31 & 6.31 & 0 & 95 \\
CapStructure & 0.02 & 0.13 & 0.002 & 0.052 \\
\hline
\end{tabular}

The coefficient analysis shown below indicates that the variables are related and thus affect the performance of the firm.

Table 2: Correlation coefficient analysis

\begin{tabular}{llll}
\hline & SCG & CO size & $\begin{array}{l}\text { Cap } \\
\text { Structure }\end{array}$ \\
\hline SCG & 1 & 0.34 & -0.01 \\
CO size & 0.34 & 1 & 0.211 \\
Cap Structure & -0.01 & 0.211 & 1 \\
\hline
\end{tabular}

Table 3: Regression coefficient

\begin{tabular}{lllll}
\hline & Coefficients & $\begin{array}{l}\text { Standard } \\
\text { Error }\end{array}$ & t Stat & P-value \\
\hline Intercept & -0.20602 & 0.012168 & -16.93087779 & 0.00347037 \\
SCG & 0.058049 & 0.002903 & 19.9956929 & 0.002491733 \\
Co size & -0.00289 & 0.000599 & -4.825699163 & 0.04035989 \\
Cap struct (adequacy ratio) & 1.199521 & 0.050913 & 23.56005335 & 0.001796701 \\
\hline Number of observations & 17 & & &
\end{tabular}

$\mathrm{VIF}=1.23$

Ad $R^{2}=0.93$

Ramsey Reset test $=0.51$

The results of the ordinary least square regression as shown in Table 3 above indicate the impact of the variables of interest on the success of a corporate. As shown by adjusted $\mathrm{R}^{2}$, of 0.93 , the model is the performance of a corporate is closely linked to sound corporate governance, company size and the capital structure among other factors, which are exogenous. The model was also subjected to Ramsey reset test the functionality of the model and it was found to be well specified. Muliticolinearity was conducted using the variance information factor (VIF) and it revealed the absence of multicolinearity as shown by the VIF of 1.23. At $5 \%$ level of significance, the model was found to be significant. The model reveals that sound corporate governance has a positive significant relationship with corporate success $5 \%$ level of significance with a $t$ value of -16.93 and a $\mathrm{p}$ - value of 0.003 . This means that sound corporate governance increases the probability of corporate success. These results are consistent with the findings by Rogers, 2006; Chiang, 2005; VO, and Phan, 2013; who found that there is a direct positive relationship between corporate governance and corporate success.

The model also revealed that company size has a negative significant relationship with corporate success with a coefficient of -0.0029 and the $p$ value 0.0404 . Though theory indicates that company size is important, the model reveals that it has a negative effect on the success of the company which might be due to managerial diseconomies of scale which might be due to bureaucracy which come to play as the company sizes increase. Other than corporate governance as a factor that influences company success, the model also revealed capital structure as a key success factor with a positive significant effect as revealed by a coefficient of 1.199 and a p-value of 0.0403 and a t- value 23.56.The findings support the studies by Chiang, 2005 and 
Kumar \& Sudesh, 2016 who also found a positive significant relationship between capital structure and corporate success.

\section{Conclusion and Recommendations}

From the research findings, it can be concluded that sound corporate governance is positively related to corporate success and as such, can minimize corporate failure. It is therefore important that companies in the Zimbabwean financial services sector give due attention to the various principles of sound corporate governance; board structure and size, board qualifications, board composition and diversity, and board practices. This justifies why the Reserve Bank of Zimbabwe (RBZ), like reserve banks in other countries, had to introduce through its Bank Licensing, Supervision and Surveillance Division, Guideline No. 01-2004/BSD on Corporate Governance for the financial services sector (Reserve Bank of Zimbabwe, 2004). The results also give basis for concluding that both capital structure and company size have a positive impact on corporate success. It is thus recommended that financial institutions continuously adherence to sound corporate governance practices to guarantee corporate success and alleviate the collapse of financial institutions as has been witnessed in the past. This is envisaged to restore confidence in the financial services sector, which is critical for its growth as more businesses and individuals transact through the formal banking system. Restoration of confidence in the sector will also attract foreign direct investment, not only to the financial services sector but other sectors of the economy as investors would derive comfort from a sound financial system in any economy. Further research could be carried out with regards the implementation of sound corporate governance in parastatals, quasi-government institutions and private sector companies in other sectors other that the financial services sector.

\section{References}

Basel Committee on Banking Supervision. (2010). Principles for enhancing corporate governance

Black, B., Jang, H. \& Kim, W. (2003). Does Corporate Governance affect Firm's Value? Working paper 327. Stanford Law School. BOFIA, (1991), Banks and Other Financial Institutions Act.

Benton, E. G. (2007). Corporate Governance in Banking: A Global Perspective. https://books.google.com > Business \& Economics > Banks \& Banking

Björklund, R. L. (2010). Corporate board governance \& the diversity-participation paradox - a note on the banking sector

Brickley, J. A., Coles, J. L. \& Jarrell, G. (1997). Leadership structure: separating the CEO and chairman of the board. Journal of Corporate Finance, 3(3), 189-220.

Bushee, B. J., Carter, M. E. \& Gerakos, J. (2007). Institutional investor preferences for corporate governance mechanisms, working paper, University of Pennsylvania.

Cadbury, S. A. (1992). Committee on Financial Aspects of Corporate Governance (the UK Cadbury

Carter, D. A., Simpkins, B. J. \& Simpson, W. G. (2003). Corporate Governance, Board Diversity, and Firm Value. Financial Review, 38(1).

Changezi, N. I. \& Saeed, A. (2013). Impact of Corporate Governance Framework on the Organizational Performance. Journal of Management Policies and Practices, 1(2).

Chiang, H. T. (2005). An Empirical Study of Corporate Governance and Corporate Performance. The Journal of Law and Economics, 31(1), 122-140.

Chidoko, C. \& Mashavira, N. (2014). An Analysis of Corporate Governance in the Banking Sector of Zimbabwe, Code), London.

Dahya, J. \& McConnell, J. J. (2007). Board Composition, Corporate Performance, and the Cadbury Committee Recommendation. Journal of Financial and Quantitative Analysis, forthcoming.

Dahya, J., McConnell, J. J. \& Travlos, N. G. (2002). The Cadbury Committee, Corporate Performance, and Top Management Turnover. Journal of Finance, 57, 461-483.

David, F., Larcker, E. C. S. \& Charles, C. Y. W. (2010). Boardroom Centrality and Stock Returns. 2010. Rock Center for Corporate Governance at Stanford University Working Paper

Dey, A., Engel, E. \& Liu, X. (2009). CEO and Board Chair Roles: To Split or Not to Split (December 16, 2009). Chicago Booth Research Paper No. 09-23. Available at SSRN: https://ssrn.com/abstract=1412827

Enobakhare, A. (2010). Corporate governance and bank performance in Nigeria. Diss. Stellenbosch: University of Stellenbosch. 
Eroke, M. O. (2007) Elements of Business Management, the Nigerian Experience, Enugu: Academic

Fairfax, L. M. (2011). The Bottom Line on Board Diversity: A Cost-Benefit Analysis of the Business Rationales for Diversity on Corporate Boards, Wis. L. 89 N.C. L. REV. 854

Faleye, O. (2007). Does One Hat Fit All? The Case of Corporate Leadership Structure. Journal of Management and Governance, 11, 239-259.

Gompers, P., Ishii, J. \& Metrick, A. (2003). Corporate Governance and Equity Prices. Journal of Economics, 118, 107-155.

Gregory, H. J. (2013). Board Composition, Diversity and Refreshment. Practical Law The Journal; Transactions \& Business. Humanities and Social Sciences Letters, 2(3), 174-180.

Hallock, K. F. (1997). Reciprocally Interlocking Boards of Directors and Executive Compensation.

Hsieh, H. \& Shannon, S. E. (2005). Three approaches to qualitative content analysis. Qualitative Health Research, 15, 1277-1288.

Jayaraman, N., Nanda, V. K. \& Ryan Jr., H. E. (2015). Does Combining the CEO and Chair Roles Cause Poor Firm Performance?Georgia Tech Scheller College of Business Research Paper No. 2015-11

Khan, H. (2011). A Literature Review of Corporate Governance. 2011 International Conference on E-business, Management and Economics IPEDR Vol.25 (2011) @ (2011) IACSIT Press, Singapore

Kumar, N. \& Sudesh, D. (2016).Corporate Governance and Banks' Performance: An Empirical Study. IOSR Journal of Business and Management (IOSR-JBM), 16, 30-35.

Larcker, D. F., So, E. C. \& Wang, C. C. Y. (2010). Boardroom Centrality and Stock Returns. Rock Center for Corporate Governance at Stanford University Working Paper.

Larcker, D. F. (2010). Board of Directors: Structure and Consequences. Center for Leadership Development \& Research Stanford Graduate School of Business

Leuz, C., Lins K. V. \& Warnock, F. E. (2007). Do foreigners invest less in poorly governed firms, Review of Financial Studies.

Levy, H. (1982). Economic evaluation of voting power of common stock. Journal of Finance, 38, 79-93.

Mahmud, W., Ahmed, S. \& Mahajan, S. (2008). Economic Reforms, Growth, and Governance: The Political Economy Aspects of Bangladesh's Development Surprise. World Bank, Washington DC.

Mettler-Toledo International Inc, February 2015, Corporate Governance Guidelines

Munzwembiri, P. (2015). Zimbabwe: Where locally owned banks have struggled to prosper, let alone survive,http://www.newzimbabwe.com/business20886Analysis+Indigenous+bank+failures/busine ss.aspx

Nguyen, B. D. (2009). Does the Rolodex Matter? Corporate Elite's Small World and the Effectiveness of Boards of Directors. Working Paper.

Okeahalam, C. \& Akinboade, O. A. (2003). A Review of Corporate Governance in Africa: Literature, Issues and Challenges, Global Corporate Governance Forum.

Palmon, 0. \& Wald, J. K. (2002). Are two heads better than one? The impact of changes in management structure on performance by firm size. Journal of Corporate Finance, 8(3), 213-226.

Reserve Bank of Zimbabwe (RBZ) Guideline No 01- 2004/BSD. Bank Licensing Supervision and Surveillance, 2004. (http://www.rbz.co.zw/assets/corporate-governance-2004.pdf).

Rogers, M. (2006). Corporate Governance and Financial Performance of Selected Commercial Banks in Uganda. Makerere University Business School, Faculty of Commerce. East Africa: Kampala Uganda.

Shungu, P., Ngirande, H. \& Ndlovu, G. (2015). Impact of Corporate Governance on the Performance of Commercial Banks in Zimbabwe. Mediterranean Journal of Social Sciences. MCSER Publishing, Rome.

Stray, S. (2008). Environmental reporting: the UK water and energy industries: a research note. Journal of Business Ethics, 80(4), 697-710.

Tesch, R. (1990), Qualitative Research: Analysis Types and Software Tools, Palmer, Bristol, PA. UNWTO News (2010), Tourism Outlook 2010, UNWTO, Madrid.

Todorović, I. (2013). Impact of Corporate Governance on Performance of Companies.

Vaithilingam, S., Mahendhiran, N. \& Muthi, S. (2006). Key drivers for soundness of the banking sector: lessons for developing countries. Journal of global business and technology, 2(1), 114-144, 163.

Vo, H. D. \& Phan, B. G. T. (2013a). Corporate governance and firm performance: Empirical evidence from listed companies on Ho Chi Minh City Stock Exchange. UEH Journal of Economic Development, 275, 115

Yang, T. \& Zhao, S. (2012). CEO Duality, Competition, and Firm Performance. School of Business, Villanova, University, Villanova, PA USA, Grenoble Ecole de Management, Cedex 01, France. 